\section{(6)}

OPEN ACCESS
'Saiseikai Utsunomiya Byoin, Utsunomiya, Tochigi, Japan ${ }^{2}$ Pulmonary Department, Keio University School of Medicine, Shinjuku, Tokyo, Japan

${ }^{3}$ Department of Internal Pulmonary Medicine, Saiseikai Utsunomiya Byoin, Utsunomiya, Tochigi, Japan

\section{Correspondence to}

Dr Ichiro Nakachi, nichiro4747@gmail.com

Accepted 9 February 2017

\title{
Intraoral ulcer due to non-invasive positive pressure ventilation: an overlooked complication
}

\author{
Katsunori Masaki, ${ }^{1,2}$ Atsushi Chiyotani, ${ }^{3}$ Ichiro Nakachi' ${ }^{2,3}$
}

\section{DESCRIPTION}

A male patient aged 81 years reported with dyspnoea and loss of consciousness, at our emergency department. His respiratory rate was 30 breaths/ min, and his level of consciousness determined using the Glasgow Coma Scale was eye (1), verbal (1) and motor (4). Despite oxygen administration via a bag valve mask, his percutaneous oxygen saturation level was measured as only $81 \%$. Physical examination revealed weak vesicular sound on auscultation, suggesting he had severe emphysema. Arterial blood gas analysis after continuous bag valve mask ventilation revealed $\mathrm{pH} 7.014$, undetectably high $\mathrm{pCO}_{2}$ and $\mathrm{pO}_{2}$ of 89 tor. The patient was admitted with the diagnosis with acute exacerbation of chronic obstructive pulmonary

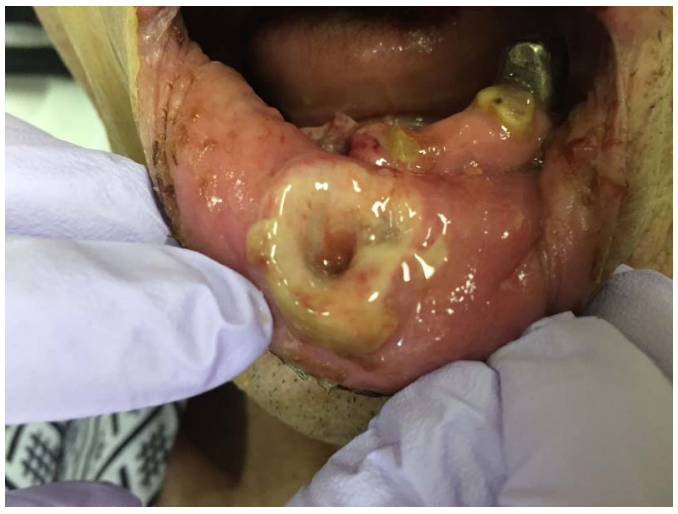

Figure 1 Lower lip ulcer against patient's teeth caused by non-invasive positive pressure ventilation pressure.

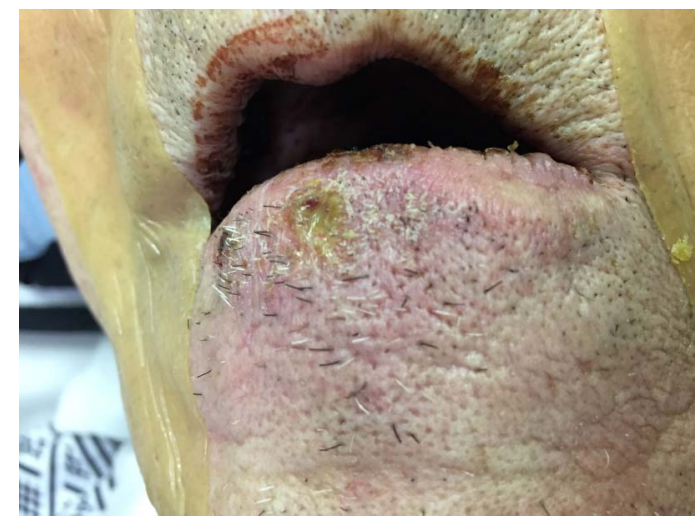

Figure 2 Ulcer penetrating the lower lip. disease (COPD). Insufficient spontaneous breathing required installation of mask-type non-invasive positive pressure ventilation (NIPPV: $\mathrm{FiO}_{2}, 0.35$, IPAP, $10 \mathrm{~cm} \mathrm{H}_{2} \mathrm{O}$, EPAP, $3 \mathrm{~cm} \mathrm{H}_{2} \mathrm{O}$ ). After continuous NIPPV support for 8 days, an intraoral ulcer was detected on the patient's lower lip (figure 1). Despite the ulcer penetrating his lip (figure 2), the patient did not complain of any pain. The continuous tight ventilator pressure caused the lesion because the patient had only two teeth on his lower jaw, which were in contact with his lip. Subsequently, the patient required another course of NIPPV owing to re-exacerbation of COPD. Hence, the only alternative was to extract the two teeth to avoid ulcer formation. Although skin ulcer due to NIPPV has been reported, ${ }^{1-3}$ and caregivers must pay attention to the exclusively internal complication in the oral cavity and the nasal bridge.

\section{Learning points}

- Non-invasive positive pressure ventilation (NIPPV) mask can cause ulcer on the nasal bridge and also in the intraoral region.

- The oral cavity should be carefully observed routinely in the case of mask NIPPV treatment.

Contributors KM wrote the article. AC edited the article. IN designed this case and wrote the article.

Competing interests None declared.

Patient consent Obtained.

Provenance and peer review Not commissioned; externally peer reviewed.

Open Access This is an Open Access article distributed in accordance with the Creative Commons Attribution Non Commercial (CC BY-NC 4.0) license, which permits others to distribute, remix, adapt, build upon this work non-commercially, and license their derivative works on different terms, provided the original work is properly cited and the use is non-commercial. See: http:// creativecommons.org/licenses/by-nc/4.0/

\section{REFERENCES}

1 Black JM, Cuddigan JE, Walko MA, et al. Medical device related pressure ulcers in hospitalized patients. Int Wound J 2010;7:358-65.

2 Stygall G, Morley K, Pickup L, et al. Acute non invasive ventilation (NIV)-related nasal bridge pressure ulceration: effect of a proactive prevention approach. Thorax 2016;71(Suppl 3):A124-5.

3 Maruccia M, Ruggieri M, Onesti MG. Facial skin breakdown in patients with non-invasive ventilation devices: report of two cases and indications for treatment and prevention. Int Wound J 2015;12:451-5. 
Copyright 2017 BMJ Publishing Group. All rights reserved. For permission to reuse any of this content visit http://group.bmj.com/group/rights-licensing/permissions.

BMJ Case Report Fellows may re-use this article for personal use and teaching without any further permission.

Become a Fellow of BMJ Case Reports today and you can:

- Submit as many cases as you like

- Enjoy fast sympathetic peer review and rapid publication of accepted articles

- Access all the published articles

- Re-use any of the published material for personal use and teaching without further permission

For information on Institutional Fellowships contact consortiasales@bmjgroup.com

Visit casereports.bmj.com for more articles like this and to become a Fellow 